\title{
The Factors Affecting the Attraction of Foreign Investors in Construction and Development of Industrial Towns in East Azerbaijan Province
} Khorrami Fard S* and Fakhimi Azar S

Management Department, Islamic Azad University of Tabriz, Tabriz, East Azerbaijan, Iran

\begin{abstract}
The aspect of investment especially foreign and industrial investor is among the major subjects in economic and financial growth and development of countries. Thus, the factors affecting investment are considered to increase the ability of countries in their competitiveness in international markets. The arrival of foreign invests to the industrial sector is an important tool to increase the supply of production resources that an increase the export capacity of the host country. The increase of production and export capacity attracts revenues, creates new job opportunities, increases technology transfer, and promotes the efficiency of production factors and finally the economic growth in the host country.

The present study was conducted with the aim of investigating a significant relationship between foreign investment and the factors affecting the attraction of foreign investor. Policy, optimal management, laws, facilities and selecting a proper place in industrial towns are among the factors studied in this study. For this purpose, a sample of 200 members is selected by random stratified sampling method. Firstly, the significant relationship between the factors is studied by using structural equation modeling (SEM) and secondly the degree of this relationship is measured. Then, the above-mentioned factors are ranked according to the importance of their effectiveness by using analytic hierarchy process (AHP). Thus, among the factors mentioned in this study, the policies adopted by the government have the maximum effect with factor load of 3.695 in the attraction of foreign investors.
\end{abstract}

Keywords: Foreign investor; industrial towns; Random stratified sampling; Structural equation modeling; Factor load; AHP

\section{Introduction}

The capital required for investment is usually supplied through two methods; First, the domestic savings of the country which are created in different economic sectors and second the savings in foreign countries. These savings are transferred in two ways of physical capital transfer flows (machineries, etc) and financial flows (cash and credits) from the source country to the host country. In other words, foreign investment is like an equation with two levels that one level includes the institutions, laws, attitudes, markets and facilities of the host country to attract foreign investment and the other level includes the tendencies and beliefs of foreign investment than the host country. Meanwhile, the role of foreign policy and establishment of positive and constructive interactions to the world outside is of great importance in forming these bilinear attitudes especially the attitudes to accept investors. The adoption of clear, planned and constructive foreign policy has a very important role in creating a positive atmosphere and institutionalizes the foreign investor about the host country in line with the attraction of foreign investment. Along with the issue of foreign investor, the privatization laws of the host country can be considered as a motivation for economic flows.

Foreign direct investment, it should be noted that the industrial development and attraction of foreign direct investment are not possible without supplying a context for the activities of the private sector in the country. In fact, privatization in a broad sense refers to a more important role to market forces in resource allocation, production system, and distribution of salable goods and services in the market. Thus, the precondition for its success is to create an appropriate context for the activity of the private sector through deregulation, ownership guarantee, modification of labor law, tax laws and make the judicial system efficient in order to address commercial claims. The presence of a big, powerful, and efficient private sector in order to take big and joint investments with foreign transnational companies provides an appropriate context to attract foreign direct investment. It indicates a close relationship between privatization and foreign direct investment. It is obvious that then regional advantage in capital transfers should be considered in order to develop in privatization strategy. According to regional strategic features, privatization causes job creation, turnover in the host country, the control of production costs in the industrial sector and finally the creation of motivation for competition in the production market and world trade. If the attraction of foreign investor in the private sector is done consciously and strategically, it will increase economic efficiency in the import and export of domestic products and income between the host country and external economy world [1].

In the meantime, the governance indicators including political stability in the private sector, monitoring quality, rule of law and corruption control have a direct effect on the attraction of foreign direct investment and private investment and the effect of corruption and political instability on foreign investors is more than all governance indicators [2].

In Iran, the policies of the government in recent years were aimed to increase investment in the private sector. The government has considered the increase of investment as one of its basic programs by applying appropriate laws and policies. However, the government has

${ }^{*}$ Corresponding author: Khorrami Fard S, Management Department, Islamic Azad University of Tabriz, Tabriz, East Azerbaijan, Iran, Tel: 98 9141164249; E-mail: samirakhorami92@gmail.com

Received June 07, 2017; Accepted August 29, 2017; Published August 31, 2017

Citation: Khorrami Fard S, Fakhimi Azar S (2017) The Factors Affecting the Attraction of Foreign Investors in Construction and Development of Industrial Towns in East Azerbaijan Province. Int J Econ Manag Sci 6: 454. doi: 10.4172/21626359.1000454

Copyright: () 2017 Khorrami Fard S, et al. This is an open-access article distributed under the terms of the Creative Commons Attribution License, which permits unrestricted use, distribution, and reproduction in any medium, provided the original author and source are credited. 
Citation: Khorrami Fard S, Fakhimi Azar S (2017) The Factors Affecting the Attraction of Foreign Investors in Construction and Development of Industrial Towns in East Azerbaijan Province. Int J Econ Manag Sci 6: 454. doi: 10.4172/2162-6359.1000454

adopted some laws and measures in order to solve some uncertainties for preventing the reduction of investment by the private sector. On the other hand, the unique and strategic geographical status of East Azerbaijan province and its adjacency with the countries of Azerbaijan, Armenia, Nakhchivan Autonomous Republic and Turkey as a key point in industrial trade corridors will bring considerable revenues through the transit of goods.

Thus, the wide volume of goods export and import from the industrial towns of East Azerbaijan province is essential. The industrial towns of East Azerbaijan province are considered as some accelerating factors in the process of national and regional economic development and one of the main circles of ground transportation and goods import/ export from neighboring countries. However, the importance of developing a strategic program to attract foreign investor is obviously felt.

\section{Research Methodology}

The two techniques of structural equation modeling and analytic hierarchy process were used to study the factors affecting the attraction of foreign investor in construction and development of industrial towns in East Azerbaijan province and determine the type and degree of this effectiveness. According to Cochran's formula at 1\% error level, a sample of 200 subjects was selected among the senior managers and officials of industrial towns in East Azerbaijan province. Two types of questionnaires were used according to the analysis method used in this study. The first questionnaire was designed for structural equation modeling with Likert scale. The second one was also designed for analytic hierarchy process according to pairwise comparisons. In this study, random stratified sampling was used. The industrial towns studied in East Azerbaijan province are Salimi town, Rajaee town, Sufian foreign investment town, Ali Nasab town, Saeed Abad town, Dizel Abad town and technology town.

Structural equation modeling is a powerful tool that helps the researcher in developing the technological framework of the study in the form of measurement and structural models. Furthermore, it provides the possibility to test the developed models as a whole by using experimental data. It provides the researcher with some indicators in order to help and guide him in modification and improvement of the model [3]. In other words, this is a powerful multiple regression method that allows the researcher to test a set of regression equations simultaneously. Foreign investment is the independent variable and policy, optimal management, laws, facilities and selecting a proper place are the dependent variables of the study. It should be noted that in the present study, the direct variables of policy, optimal management, laws, facilities and selecting a proper place cannot be measured directly and for this reason they are considered as latent variable. Each latent variable is measured by observed variable. Figure 1 is the conceptual model of the study derived from the theoretical foundations. In this model, the latent variables are located inside the oval and the observed variables are located inside the rectangles.

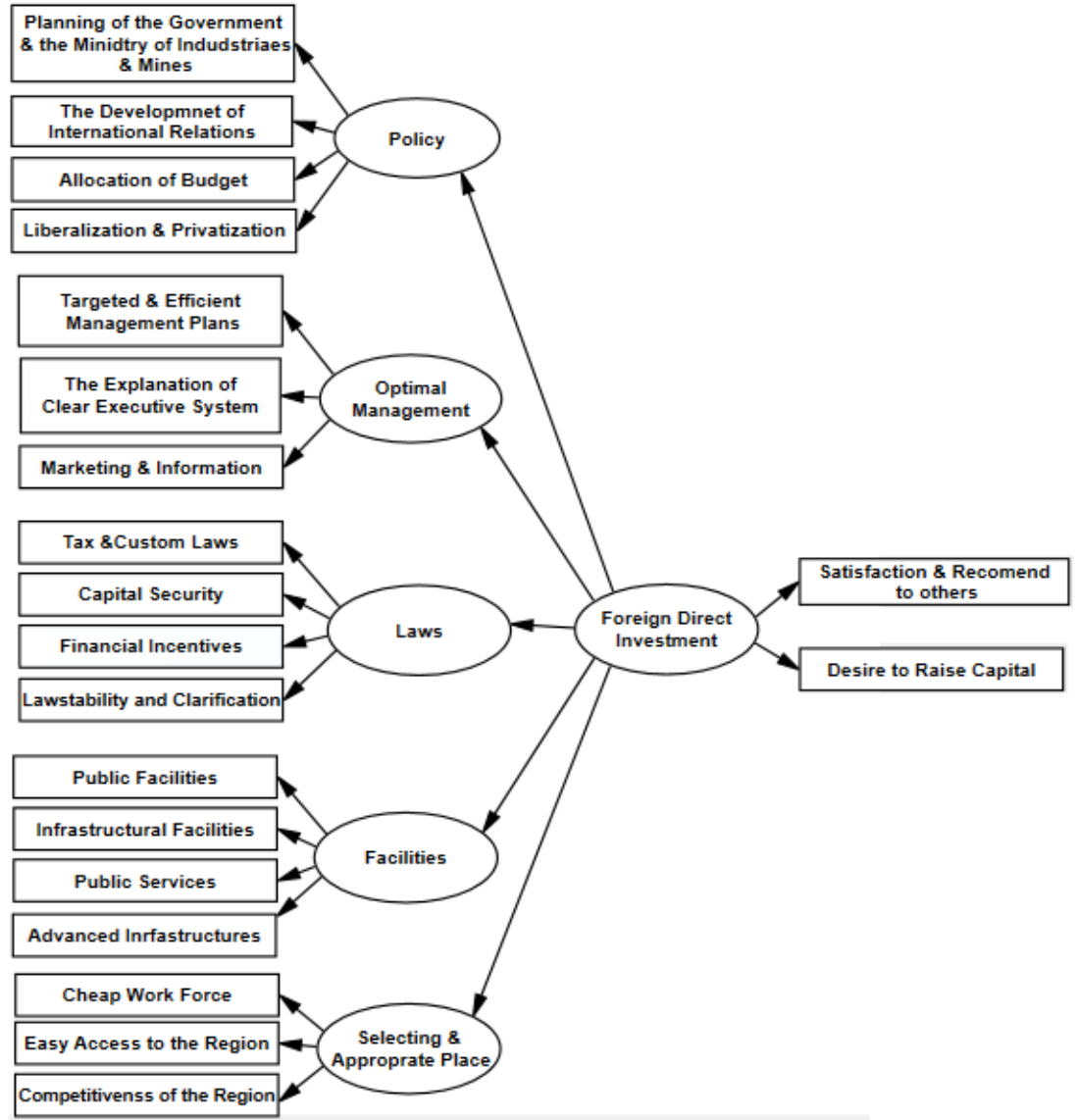

Figure 1: The primary conceptual model to study the factors affecting the attraction of foreign investors in the industrial towns in East Azerbaijan Province by using structural equation modeling. 
Citation: Khorrami Fard S, Fakhimi Azar S (2017) The Factors Affecting the Attraction of Foreign Investors in Construction and Development of Industrial Towns in East Azerbaijan Province. Int J Econ Manag Sci 6: 454. doi: 10.4172/2162-6359.1000454

Then, the ranking of factors and the options representing the factors were discussed by using analytic hierarchy process. Decision-making is raised as the selection of one option among the current options or privatization of options. Multiple-criteria decision-making (MCDM) methods have been considered in recent years. Meanwhile, the analytic hierarchy process has been used more than the other methods in the science of management. Analytic hierarchy process (AHP) reflects the natural behavior and human thinking on the numerical results of the study. This technique studies complicated problems according to their mutual effects as paired, converts them into simple problems and solves them.

Analytic hierarchy process can be used when decision-making is faced with some options of competitor and decision-making criterion. The decision-maker starts making decisions by providing a hierarchical tree. Hierarchical tree indicates the compared factors and evaluated competitor options in decision. In these comparisons, the weight of each factor is determined in line with the conceptual model [4]. Figure 2 indicates the conceptual model of a decision tree. The hierarchical decision tree includes the target level (the amount of attracting foreign investors), the level of main factors and the levels of options (the subfactors affecting the target). It should be noted that the data of the first level are obtained indirectly with the help of options.

\section{Results and Discussion}

Firstly, according to Figure 3, a model is designed as the primary proposed model for analysis. In this model, the variable inside the oval (foreign direct investment (FDI), policy (PO), optimal management $(\mathrm{M})$, laws (L), facilities (F) and selecting an appropriate place $(\mathrm{P})$ ) are recognized as latent variables and the variables inside the rectangles are recognized as observed variables. The arrows indicate the relationships between the variables. This model consists of measurement model X, measurement model $\mathrm{Y}$ and structural equation model. e1, e $2 \ldots$ and e18 are the errors of independent observed variables and error 1 and error 2 are the errors of dependent observed variables.

Goodness of Fit Indices for the mentioned model was shown in Table 1.

Since the fit indices of this model are unacceptable and unfavorable, thus the primary model was modified and the final mode was developed by applying the relationships between some variables. The modified model is shown as the final model in Figures 4 and 5. The fit indices values of the final model were given in Table 2 .
According to Goodness of Fit Indices for the model, it can be concluded that the final model is correct and acceptable in description of the type of the relationship between dependent and independent variables and has an appropriate accuracy and validity. Thus, the significant relationship between the independent variables of policy, optimal management, laws, facilities and selecting a proper place and the dependent variable of foreign direct investment (FDI) is confirmed at $95 \%$ confidence level. Also, the values estimated by the model to explain the amount of this relationship are acceptable at $95 \%$ confidence level.

Table 3 includes these estimated values as model parameters (regression coefficients), standard deviation, critical value and standardized regression coefficient (factor load).

Critical value is obtained through dividing the estimated parameter value by standard deviation. This value, like $p$-value, is sued to study the significance of a parameter. Thus, if this value is less than 1.96 and more than -1.96 , the null hypothesis of the parameter and the lack of a significant relationship between the variables at $0.05 \%$ level are accepted.

Also, the power of the relationship between latent variable and observed variable is shown by factor load. Factor load is a value between zero and one. If the factor load is less than 0.3 , the relationship will be considered as weak and it will be disregarded. The factor load between 0.3 and 0.6 is acceptable and if it is bigger than 0.6 , it will be very optimal [5]. In the following table, the significance of regression coefficients at $1 \%$ and $5 \%$ levels was shown according to $p$-value.

According to the above discussions and included results in the above table, the independent variables of policy, optimal management, laws, facilities and selecting a proper place affect the construction and development of industrial towns and the amount of this effectiveness equals the factor loads (standardized regression coefficients) of 0.888 , $0.343,0.741,0.531$ and 0.802 . The variable of policy with the factor load of 0.888 has the maximum effect on the attraction of foreign investors.

Four variables of the planning of the government and the Ministry of Industries and Mines, the development of international relations, allocation of budget and liberalization and privatization are significant in explaining the latent variable (policy). Factor loads (standardized regression coefficients) with values of $0.738,-0.172,0.785$ and 0.870 at $1 \%$ level have a significant difference with zero. The maximum effect is related to the variable of liberalization and privatization. In other

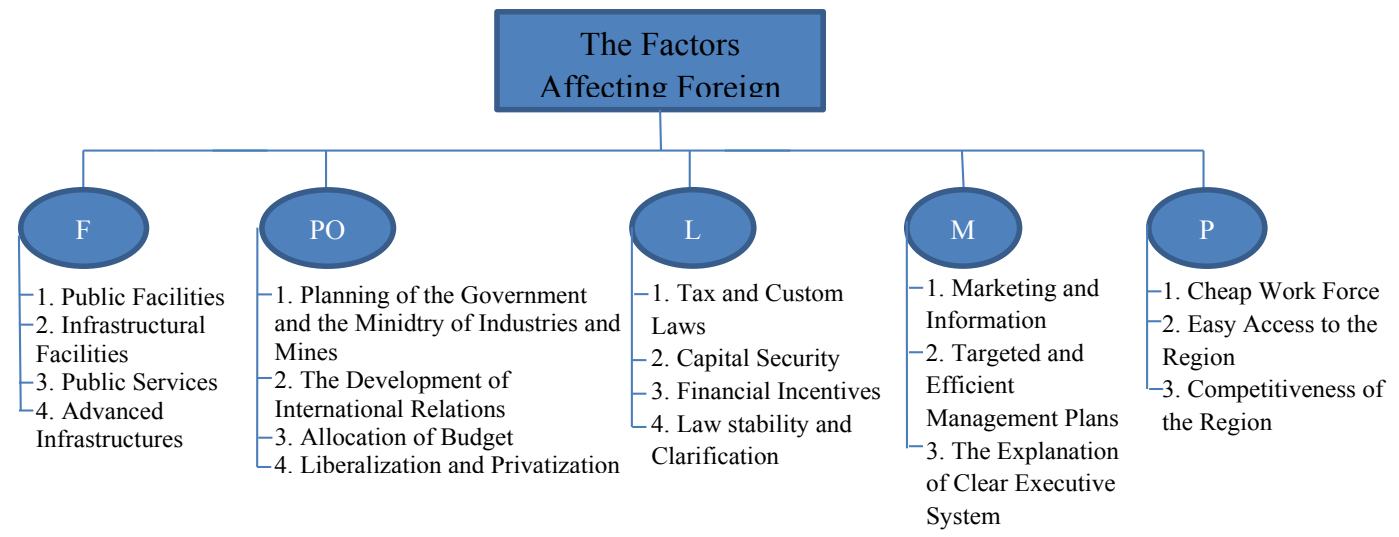

Figure 2: Hierarchical structure to evaluate the factors affecting foreign investment in industrial towns in East Azerbaijan Province. 
Citation: Khorrami Fard S, Fakhimi Azar S (2017) The Factors Affecting the Attraction of Foreign Investors in Construction and Development of Industrial Towns in East Azerbaijan Province. Int J Econ Manag Sci 6: 454. doi: 10.4172/2162-6359.1000454

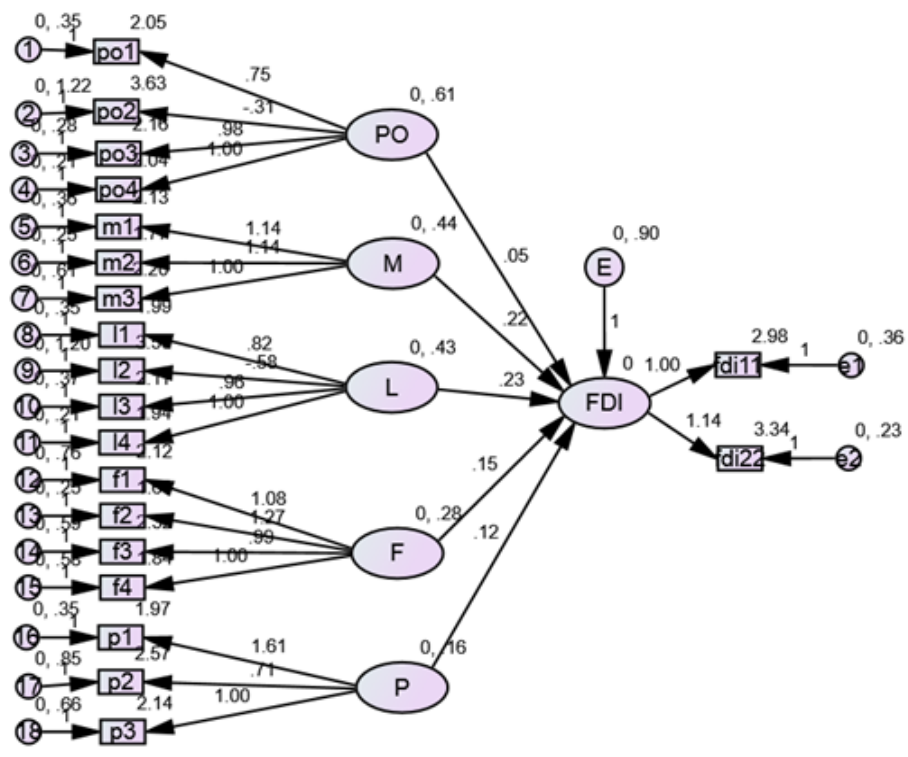

\section{$\mathrm{Chi}^{\wedge} 2=674.481 \quad$ (D.F. $\left.=165\right) \quad \mathrm{P}-$ Value $=.000$ \\ $\mathrm{CFI}=.661, \mathrm{NFI}=.602, \mathrm{TLI}=.610, \mathrm{RMSEA}=.125$}

Figure 3: The primary proposed model to study the factors affecting foreign investors.

\begin{tabular}{|c|c|c|c|}
\hline Fit Index & Fit Name & $\begin{array}{c}\text { Primary Model } \\
\text { (Proposed) }\end{array}$ & Acceptable value \\
\hline \multirow[t]{3}{*}{ Absolute Fit Indices } & Chi-Square Level (CIMIM or $x^{2}$ ) & 674.481 & The smaller the better \\
\hline & The Significant Amount of Test Level (P-Value) & 0 & Value between 0.05 to 1 \\
\hline & Degrees of Freedom (DF) & 165 & The smaller the better \\
\hline \multirow[t]{5}{*}{ Comparative Fit Indices } & Normed Fit Index (NFI) & 0.602 & Value between 0.09 to 1 \\
\hline & Tucker-Lewis Index (TLI) or (NNFI) & 0.61 & Value between 0.09 to 1 \\
\hline & Comparative Fit Index (CFI) & 0.661 & Value between 0.09 to 1 \\
\hline & Incremental Fit Index (IFI) & 0.667 & Value between 0.09 to 1 \\
\hline & Relative Fit Index (RFI) & 0.541 & Value between 0.09 to 1 \\
\hline \multirow[t]{3}{*}{ Parsimonious Fit Indices } & Root Mean Square Error of Approximation (RMSEA) & 0.125 & Value between 0.05 to 1 \\
\hline & Normed Chisquare $\left(\frac{\mathrm{CMIN}}{\mathrm{df}}\right.$ or $\left.\frac{\chi^{2}}{\mathrm{df}}\right)$ & 4.088 & Value between 1 to 3 \\
\hline & Parsimonious Normed Fit Index (PNFI) & 0.522 & Value between 0.06 to 1 \\
\hline
\end{tabular}

Table 1: The values of Goodness of Fit Index for the primary model.

\begin{tabular}{|c|c|c|c|}
\hline Fit Index & Fit Name & Modified Model & Acceptable value \\
\hline \multirow[t]{3}{*}{ Absolute fit indices } & Chi-Square Level (CIMIM or $\left.X^{2}\right)$ & 167.109 & The smaller the better \\
\hline & The Significant Amount of Test Level (P-Value) & 0.257 & Value between 0.05 to 1 \\
\hline & Degrees of Freedom (DF) & 156 & The smaller the better \\
\hline \multirow[t]{5}{*}{ Comparative fit indices } & Normed Fit Index (NFI) & 0.901 & Value between 0.09 to 1 \\
\hline & Tucker-Lewis Index (NNFI) or (TLI) & 0.991 & Value between 0.09 to 1 \\
\hline & Comparative Fit Index (CFI) & 0.993 & Value between 0.09 to 1 \\
\hline & Incremental Fit Index (IFI) & 0.993 & Value between 0.09 to 1 \\
\hline & Relative Fit Index (RFI) & 0.88 & Value between 0.09 to 1 \\
\hline \multirow[t]{3}{*}{ Parsimonious Fit Indices } & Root Mean Square Error of Approximation (RMSEA) & 0.019 & Value between 0 to 0.05 \\
\hline & Normed Chisquare $\left(\frac{\mathrm{MIN}}{\mathrm{df}}\right.$ or $\left.\frac{\chi^{2}}{\mathrm{df}}\right)$ & 1.071 & Value between 1 to 3 \\
\hline & Parsimonious Normed Fit Index (PNFI) & 0.74 & Value between 0.06 to 1 \\
\hline
\end{tabular}

Table 2: The Goodness of Fit values for the modified model. 
Citation: Khorrami Fard S, Fakhimi Azar S (2017) The Factors Affecting the Attraction of Foreign Investors in Construction and Development of Industrial Towns in East Azerbaijan Province. Int J Econ Manag Sci 6: 454. doi: 10.4172/2162-6359.1000454

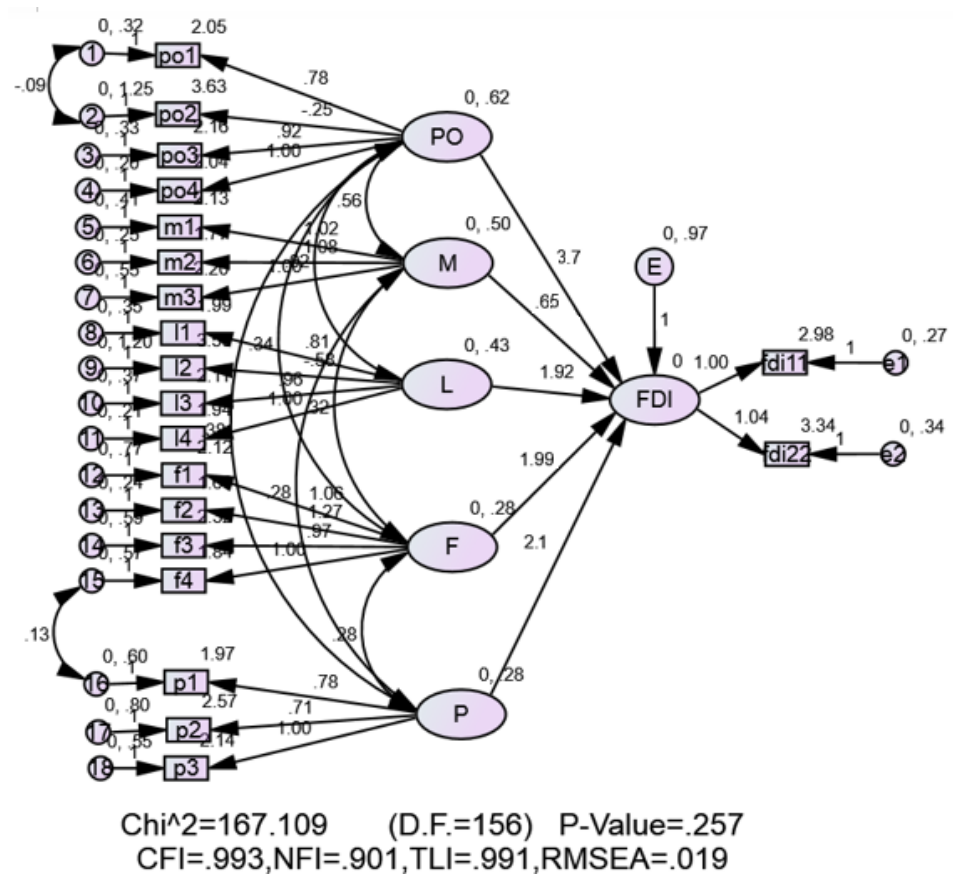

Figure 4: The final modified model at non-standardized mode to study the affecting foreign investors in industrial towns in East Azerbaijan Province.

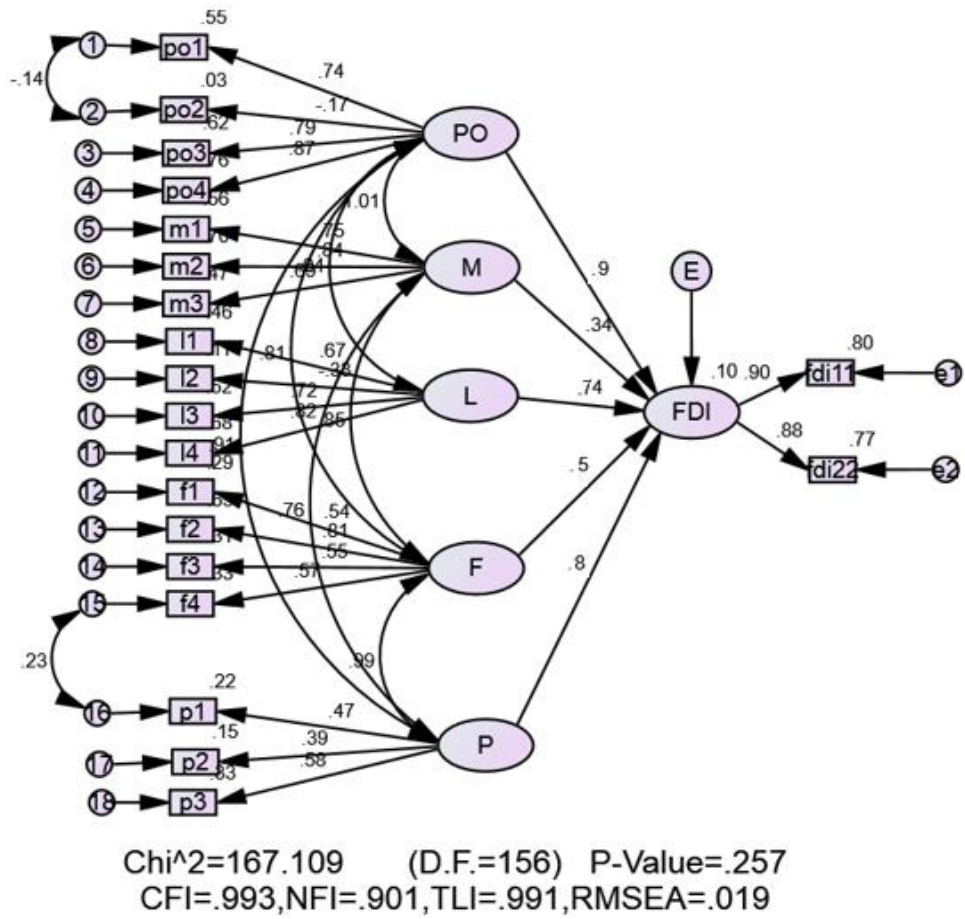

Figure 5: Final modified model at standardized mode to study the affecting foreign investors in industrial towns in East Azerbaijan Province.

words, the variance related to policy increases to 0.780 for liberalization and privatization in industrial towns. In addition, the variable of budget allocation with the factor load of 0.785 means that the variance related to policy increases to 0.785 for one unit of increase in the variable of budget allocation. Furthermore, the variable of the development of industrial relations had a weak performance with the factor load of -0.127 in explaining the independent latent variable of policy.
To explain the latent variable (optimal management), three variables of marketing and information, targeted and efficient $t$ management plans, the explanation of clear executive system were included in the model which explain the latent variable of optimal management well. These variables have the factor loads of $0.746,0.837$, and 0.689 respectively. As can be observed, the maximum effect is related to the two variables of marketing- information and targeted and efficient $t$ 
Citation: Khorrami Fard S, Fakhimi Azar S (2017) The Factors Affecting the Attraction of Foreign Investors in Construction and Development of Industrial Towns in East Azerbaijan Province. Int J Econ Manag Sci 6: 454. doi: 10.4172/2162-6359.1000454

Page 6 of 10

\begin{tabular}{|c|c|c|c|c|}
\hline Variables and Type of Relationship & Regression Coefficient & The Standard Deviation & Critical Ratio & Standardized Regression Coefficients \\
\hline $\mathrm{PO} \rightarrow \mathrm{FDI}$ & 3.695 & 1.152 & 3.207 & 0.881 \\
\hline $\mathrm{M} \rightarrow \mathrm{FDI}$ & 0.651 & 0.342 & 1.904 & 0.343 \\
\hline $\mathrm{L} \rightarrow \mathrm{FDI}$ & 1.918 & 0.69 & 2.779 & 0.742 \\
\hline $\mathrm{F} \rightarrow \mathrm{FDI}$ & 1.996 & 1.003 & 1.99 & 0.531 \\
\hline $\mathrm{P} \rightarrow \mathrm{FDI}$ & 2.086 & 0.697 & 2.993 & 0.802 \\
\hline $\mathrm{PO} \rightarrow \mathrm{po} 4$ & 1 & - & - & 0.87 \\
\hline $\mathrm{PO} \rightarrow \mathrm{po} 3$ & 0.924 & 0.067 & 13.83 & 0.785 \\
\hline $\mathrm{PO} \rightarrow \mathrm{po} 2$ & -0.246 & 0.105 & -2.351 & -0.172 \\
\hline $\mathrm{PO} \rightarrow \mathrm{po} 1$ & 0.778 & 0.063 & 12.307 & 0.738 \\
\hline $\mathrm{M} \rightarrow \mathrm{m} 3$ & 1 & - & - & 0.689 \\
\hline$M \rightarrow m 2$ & 1.079 & 0.1 & 10.832 & 0.837 \\
\hline $\mathrm{M} \rightarrow \mathrm{m} 1$ & 1.021 & 0.104 & 9.773 & 0.746 \\
\hline $\mathrm{L} \rightarrow \mathrm{I4}$ & 1 & - & - & 0.824 \\
\hline $\mathrm{L} \rightarrow \mathrm{I} 3$ & 0.962 & 0.113 & 8.523 & 0.721 \\
\hline $\mathrm{L} \rightarrow \mathrm{I} 2$ & -0.577 & 0.142 & -4.051 & -0.328 \\
\hline $\mathrm{L} \rightarrow \mathrm{I} 1$ & 0.315 & 0.1 & 8.137 & 0.675 \\
\hline$F \rightarrow f 4$ & 1 & - & - & 0.572 \\
\hline$F \rightarrow f 3$ & 0.971 & 0.159 & 6.123 & 0.554 \\
\hline$F \rightarrow f 2$ & 1.27 & 0.166 & 7.647 & 0.806 \\
\hline $\mathrm{F} \rightarrow \mathrm{f} 1$ & 1.056 & 0.177 & 5.961 & 0.536 \\
\hline $\mathrm{P} \rightarrow \mathrm{po} 3$ & 1 & - & - & 0.578 \\
\hline $\mathrm{P} \rightarrow \mathrm{po} 2$ & 0.712 & 0.152 & 4.682 & 0.387 \\
\hline $\mathrm{P} \rightarrow \mathrm{po1}$ & 0.778 & 0.138 & 5.65 & 0.468 \\
\hline FDI $\rightarrow$ fdi 1 & 1 & - & - & 0.896 \\
\hline $\mathrm{FDI} \rightarrow$ fdi2 & 1.039 & 0.354 & 2.936 & 0.879 \\
\hline
\end{tabular}

Table 3: The estimated values of parameters and standardized regression coefficients (factor load).

management plans. It means that the variance related to the variable of optimal management increases to 0.746 and 0.837 respectively with the increase of the variables (marketing and information) and (targeted and efficient $t$ management plans).

To explain the latent variable (laws) in the secondary model, four observed variables of tax and custom laws, capital security, financial incentives, and law stability and clarification have the factor loads of $0.675,-0.328,0.721$ and 0.824 respectively. The maximum effect is related to the variable of law stability and clarification. It means that the variance related to laws increases to 0.824 for one unit of increase in the variable (law stability and clarification). In addition, the variable of capital security was weak in explaining the latent variable of laws with the factor load of -0.328 .

To explain the latent variable (facilities) in the secondary model, four observed variables of public facilities, infrastructural facilities, public services and advanced infrastructures have a significant relationship with the latent variable of facilities and the null hypothesis as their zero regression coefficients is rejected. Furthermore, these variables have the factor loads of $0.536,0.806,0.554$ and 0.572 respectively that is a good and acceptable relationship. The maximum effect is related to the variable (infrastructural facilities) which means that the variance related to this latent variance increases to 0.806 for one unit of increase in the variable (infrastructural facilities).

To explain the latent variable (place) in the modified model, three observed variables of access to cheap work force, easy access to the region, and competitiveness of the region can be referred to. All these variables have a significant relationship to the latent variable (place) at $0 / 01$ level. They have the factor load of $0.468,0.387$ and 0.578 which show a good and optimal relationship between the latent and observed variables.

\begin{tabular}{|c|c|c|c|c|}
\hline $\begin{array}{c}\text { Corresponding } \\
\text { Variables }\end{array}$ & Covariance & $\begin{array}{c}\text { The Standard } \\
\text { Deviation }\end{array}$ & $\begin{array}{c}\text { Critical } \\
\text { Ratio }\end{array}$ & $\begin{array}{c}\text { Correlation } \\
\text { Coefficients }\end{array}$ \\
\hline $\mathrm{M} \rightarrow \mathrm{F}$ & 0.317 & 0.057 & 5.575 & 0.849 \\
\hline $\mathrm{PO} \rightarrow \mathrm{F}$ & 0.337 & 0.058 & 5.862 & 0.807 \\
\hline $\mathrm{PO} \rightarrow \mathrm{M}$ & 0.564 & 0.075 & 7.516 & 1.012 \\
\hline $\mathrm{P} \rightarrow \mathrm{F}$ & 0.276 & 0.052 & 5.29 & 0.995 \\
\hline $\mathrm{P} \rightarrow \mathrm{M}$ & 0.283 & 0.055 & 5.155 & 0.762 \\
\hline $\mathrm{P} \rightarrow \mathrm{PO}$ & 0.377 & 0.061 & 6.153 & 0.907 \\
\hline $\mathrm{PO} \rightarrow \mathrm{L}$ & 0.062 & 0.022 & 2.863 & 0.036 \\
\hline $15 \rightarrow 16$ & 0.132 & 0.047 & 2.788 & 0.225 \\
\hline $2 \rightarrow 1$ & -0.093 & 0.047 & -1.98 & -0.142 \\
\hline \multicolumn{4}{|c|}{ Table 4: Covariance and correlation coefficients. } \\
\hline
\end{tabular}

To explain the latent variable (foreign investment) in the secondary model, the two observed variables of tendency to in the increase of investment, satisfaction and suggestion to others for investment have a significant relationship with the latent variable. The factor loads of these two variables are respectively 0.896 and 0.879 . The maximum effect is related to the variable (tendency the increase of investment).

In Table 4, the values of covariance and correlation between the variables were shown to evaluate the bilateral relations. As was mentioned in the research mythology, the analytic hierarchy process was sued to rank the importance of the effectiveness of the studied factors on the attraction of foreign investor. The first step of ranking is to draw a conceptual model according to the theoretical foundations of the study as shown in Figure 1. According to the primary conceptual model, the research variables are introduced in Expert Choice software and their weights are calculated by using pairwise comparisons. It should be noted that making the matrix of pairwise comparison for the variables is necessary in order to determine the importance of the criteria. The primary data are obtained through a questionnaire according to the analytic hierarchy process and the scaling reported in 
Citation: Khorrami Fard S, Fakhimi Azar S (2017) The Factors Affecting the Attraction of Foreign Investors in Construction and Development of Industrial Towns in East Azerbaijan Province. Int J Econ Manag Sci 6: 454. doi: 10.4172/2162-6359.1000454

Table 5. The geometric mean of the collected data forms the values of pairwise comparisons matrix.

After the normalization of the numbers of pairwise comparison matrix, the weight of each variable can be determined. The results were shown in Figure 6.

According to the values shown in the figure, the maximum importance for the variable of policy is the most important factor affecting foreign investment with the weight of 0.327 . Laws, optimal management, infrastructural facilities and place are at the next ranks of importance.

\section{The determination of the importance of sub-criteria for each main criterion}

Multiple decision-makings, as the main variables affecting the attraction of foreign investment, are divided into separate sub-sets that each one can affect the attraction of foreign investment. The determination of the weight and importance coefficient of the above factors can be done as a useful and effective measure for economic planners in order to attract more foreign investments in industrial towns (Table 6).

\begin{tabular}{|c|c|c|c|c|c|}
\hline Foreign Investment & Laws & Policy & Management & Facilities & Place \\
\hline Laws & 1 & 0.8516 & 1.1103 & 1.1023 & 1.0345 \\
\hline Policy & 0.7374 & 1 & 1.1609 & 1.1125 & 1.0968 \\
\hline Optimal Management & 0.8091 & 0.7865 & 1 & 1.0875 & 1.1123 \\
\hline Facilities & 0.8512 & 0.8501 & 0.8819 & 1 & 1.1054 \\
\hline Place & 0.8625 & 0.8312 & 0.7521 & 0.9123 & 1 \\
\hline
\end{tabular}

Table 5: Pairwise comparisons matrix of foreign investment.
To determine the importance of each factor in industrial towns, the pairwise comparisons matrix is adjusted to implement the comparisons.

After the normalization of the above matrix numbers, the weight of each variable can be determined by using the geometric mean. The results were given in Figure 7.

According to the obtained values, the maximum importance was given to the variable of capital security with the weight of 0.408 among the sub-groups of laws (Table 7).

After the normalization of the above matrix numbers, the weight of each variable can be determined by using the geometric mean. The results were given in Figure 8.

According to the obtained values, the maximum importance was given to the variable of liberalization and privatization with the weight of 0.526 among the sub-groups of government policies (Table 8).

After the normalization of the above matrix numbers, the weight of each variable can be determined by using the geometric mean. The results were given in Figure 9.

According to the obtained values, the maximum importance was given to the variable of explanation of clear executive with the weight of 0.567 among the sub-groups of optimal management (Table 9).

After the normalization of the above matrix numbers, the weight of each variable can be determined by using the geometric mean. The results were given in Figure 10.

According to the obtained values, the maximum importance was

\begin{tabular}{|c|c|c|c|}
\hline Government Laws & $\begin{array}{c}\text { Tax and Custom } \\
\text { Laws (L1) }\end{array}$ & $\begin{array}{c}\text { Capital Security } \\
\text { (L2) }\end{array}$ & $\begin{array}{c}\text { Financial Incentives } \\
\text { (L3) }\end{array}$ \\
\hline Tax and Custom Laws & 1 & 0.8527 & 0.9511 \\
\hline Capital Security & 0.7374 & 1 & 0.9609 \\
\hline Financial Incentives & 0.8091 & 1.0345 & 1 \\
\hline Law Stability and Clarification & 0.8512 & 0.8231 & 1.1867 \\
\hline
\end{tabular}

Table 6: Pairwise comparisons matrix of government laws.

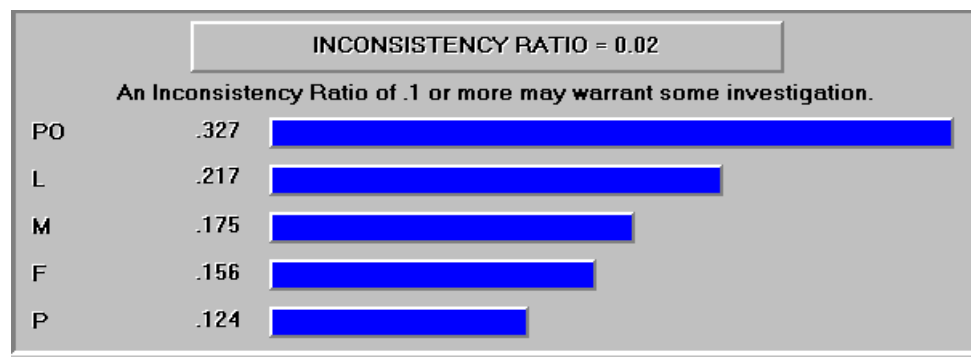

Figure 6: The final weight criteria for foreign investment.

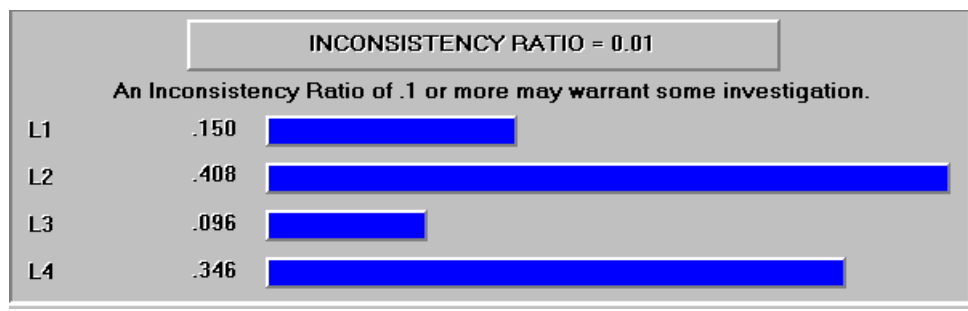

Figure 7: The final weight criteria for government laws. 
Citation: Khorrami Fard S, Fakhimi Azar S (2017) The Factors Affecting the Attraction of Foreign Investors in Construction and Development of Industrial Towns in East Azerbaijan Province. Int J Econ Manag Sci 6: 454. doi: 10.4172/2162-6359.1000454

Page 8 of 10

\begin{tabular}{|c|c|c|c|c|}
\hline Government Policies & $\begin{array}{l}\text { Planning of the } \\
\text { Government (PO1) }\end{array}$ & $\begin{array}{c}\text { Development of International } \\
\text { Relations (PO2) }\end{array}$ & $\begin{array}{l}\text { Allocation of } \\
\text { Budget (PO3) }\end{array}$ & $\begin{array}{l}\text { Liberalization and } \\
\text { Privatization (PO4) }\end{array}$ \\
\hline Planning of the Government & 1 & 0.7505 & 0.7822 & 0.7302 \\
\hline Development of International Relations & 1.1125 & 1 & 1.1609 & 0.7374 \\
\hline Allocation of Budget & 0.7652 & 1.1825 & 1 & 0.8533 \\
\hline Liberalization and Privatization & 0.5232 & 1.0651 & 0.5412 & 1 \\
\hline
\end{tabular}

Table 7: Pairwise comparisons matrix of government policies.

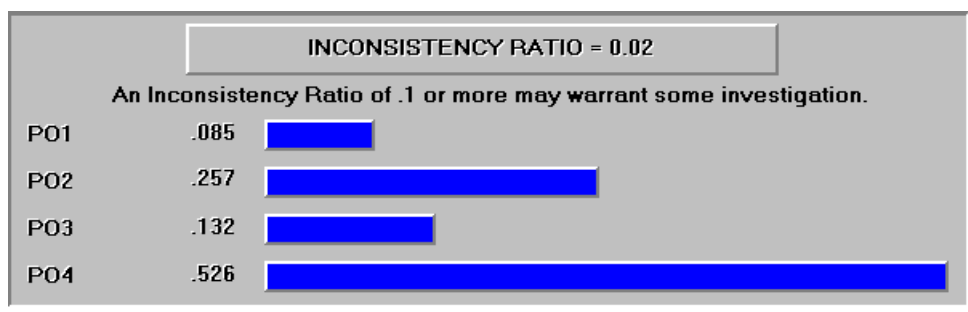

Figure 8: The final weight criteria for government policies.

\begin{tabular}{|c|c|c|c|}
\hline Optimal Management & $\begin{array}{l}\text { Marketing and Information } \\
\text { (M1) }\end{array}$ & $\begin{array}{l}\text { Targeted and Efficient } \\
\text { Management Plans (M2) }\end{array}$ & $\begin{array}{l}\text { Explanation of Clear } \\
\text { Executive System (M3) }\end{array}$ \\
\hline Marketing and Information & 1 & 0.8502 & 0.8822 \\
\hline Targeted and Efficient Management Plans & 1.0144 & 1 & 0.9254 \\
\hline Explanation of Clear Executive System & 0.0113 & 1.0502 & 1 \\
\hline
\end{tabular}

Table 8: Pairwise comparisons matrix of optimal management.

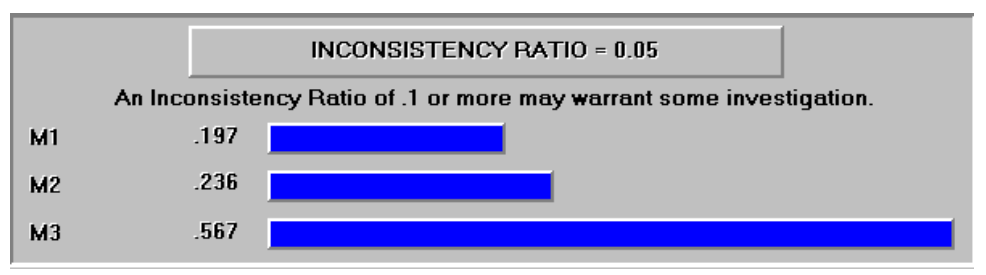

Figure 9: The final weight criteria for optimal management.

\begin{tabular}{|c|c|c|c|c|}
\hline Facilities & Public Facilities (F1) & Infrastructural Facilities (F2) & Public Services (F3) & $\begin{array}{l}\text { Advanced Infrastructures } \\
\text { (F4) }\end{array}$ \\
\hline Public Facilities & 1 & 0.9865 & 0.8401 & 0.7021 \\
\hline Infrastructural Facilities & 0.9303 & 1 & 0.8354 & 0.9807 \\
\hline Public Services & 0.8532 & 0.9923 & 1 & 0.9786 \\
\hline Advanced Infrastructures & 1.1403 & 1.0345 & 1.1109 & 1 \\
\hline
\end{tabular}

Table 9: Pairwise comparisons matrix of facilities.

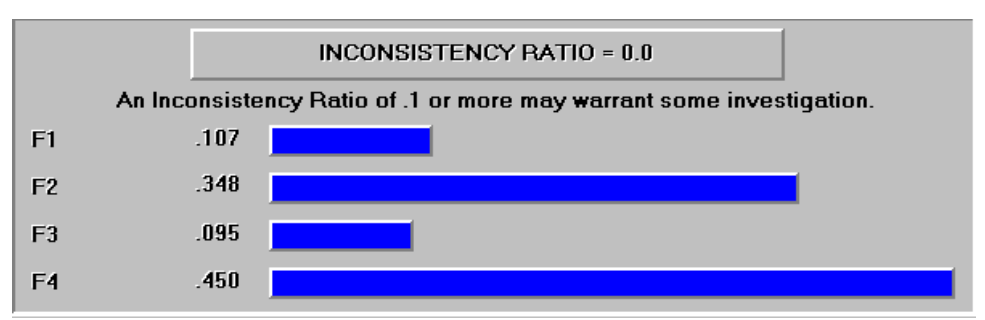

Figure 10: The final weight criteria for facilities.

given to the variable of advanced infrastructures with the weight of 0.450 among the sub-groups of facilities (Table 10).

After the normalization of the above matrix numbers, the weight of each variable can be determined by using the geometric mean. The results were given in Figure 11.
According to the obtained values, the maximum importance was given to the variable of competitiveness of the region with the weight of 0.745 among the sub-groups of place.

In order to trust the weights obtained from Table 11, the inconsistency rate should be less than 0.1 . The inconsistency rate of 
Citation: Khorrami Fard S, Fakhimi Azar S (2017) The Factors Affecting the Attraction of Foreign Investors in Construction and Development of Industrial Towns in East Azerbaijan Province. Int J Econ Manag Sci 6: 454. doi: 10.4172/2162-6359.1000454

Page 9 of 10

\begin{tabular}{|c|c|c|c|}
\hline Place & Cheap Work Force (P1) & Easy Access to the Region (P2) & Competitiveness of the Region (P3) \\
\hline Cheap Work Force & 1 & 1.1109 & 1.0123 \\
\hline Easy Access to the Region & 0.9862 & 1 & 0.8421 \\
\hline Competitiveness of the Region & 1.0134 & 1.1103 & 1 \\
\hline
\end{tabular}

Table 10: Pairwise comparisons matrix of place.

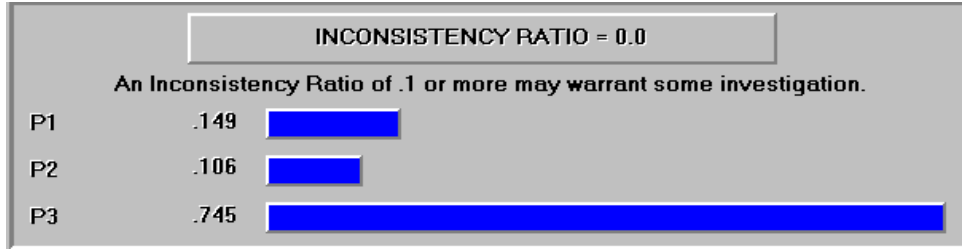

Figure 11: The final weight criteria for place.

\begin{tabular}{|c|c|}
\hline Criteria & Inconsistency Rate \\
\hline Foreign Investment & 0.02 \\
\hline Government Laws & 0.01 \\
\hline Government Policies & 0.02 \\
\hline Optimal Management & 0.05 \\
\hline Facilities & 0 \\
\hline Place & 0 \\
\hline
\end{tabular}

Table 11: The inconsistency rate of Pairwise comparisons matrix for each criteria.

variables was calculated in the following table.

Since the inconsistency rate is less than the experimental value 0.1 , thus it can be said that the group matrix has inconsistency and prioritizations are reliable.

\section{Conclusion}

According to the results obtained from structural equation modeling, testing the statistical hypotheses of the study is as follows:

Research hypothesis: There is a significant relationship between the variable of "policy by the government" and the rate of attracting foreign investors in construction and development of industrial towns in East Azerbaijan province.

The significant relationship between the variable of policy by the government and foreign investors is confirmed with regression coefficient (3.695) at 95\% confidence level. With the factor load of 0.881 , it allocated the maximum amount of changes on foreign investor than the other variables. And the statistical hypothesis of the study is acceptable.

Research hypothesis: There is a significant relationship between the variable of "optimal management" and the rate of attracting foreign investors in construction and development of industrial towns in East Azerbaijan province.

The significant relationship between the variable of policy by the government and foreign investors is confirmed with regression coefficient (0.651) at $95 \%$ confidence level and the statistical hypothesis of the study is acceptable.

Research hypothesis: There is a significant relationship between the variable of "laws" and the rate of attracting foreign investors in construction and development of industrial towns in East Azerbaijan province.

The significant relationship between the variable of policy by the government and foreign investors is confirmed with regression coefficient (1.918) at 95\% confidence level and the statistical hypothesis of the study is acceptable.

Research hypothesis: There is a significant relationship between the variable of "facilities" and the rate of attracting foreign investors in construction and development of industrial towns in East Azerbaijan province.

The significant relationship between the variable of policy by the government and foreign investors is confirmed with regression coefficient (1.996) at 95\% confidence level and the statistical hypothesis of the study is acceptable.

Research hypothesis: There is a significant relationship between the variable of "place" and the rate of attracting foreign investors in construction and development of industrial towns in East Azerbaijan province.

The significant relationship between the variable of policy by the government and foreign investors is confirmed with regression coefficient (2.086) at 95\% confidence level and the statistical hypothesis of the study is acceptable.

According to the results obtained from ranking the importance of the factors affecting the attraction of foreign investment in construction and development of industrial towns are as follows:

- The top high priority between the main factors to increase the attraction of foreign investors in construction and development of industrial towns in East Azerbaijan province with the relative weight of 0.327 belongs to the factor "policy by the government".

- The top high priority between the sub- factors related to policy made by the government to increase the attraction of foreign investors in construction and development of industrial towns in East Azerbaijan province with the relative weight of 0.526 belongs to the factor "liberalization and privatization".

- The top high priority between the sub- factors related to laws to increase the attraction of foreign investors in construction and development of industrial towns in East Azerbaijan province with the relative weight of 0.408 belongs to the factor "liberalization and privatization".

- The top high priority between the sub- factors related to optimal management to increase the attraction of foreign 
Citation: Khorrami Fard S, Fakhimi Azar S (2017) The Factors Affecting the Attraction of Foreign Investors in Construction and Development of Industrial Towns in East Azerbaijan Province. Int J Econ Manag Sci 6: 454. doi: 10.4172/2162-6359.1000454

Page 10 of 10

investors in construction and development of industrial towns in East Azerbaijan province with the relative weight of 0.567 belongs to the factor "liberalization and privatization".

- The top high priority between the sub- factors related to facilities to increase the attraction of foreign investors in construction and development of industrial towns in East Azerbaijan province with the relative weight of 0.450 belongs to the factor "liberalization and privatization".

- The top high priority between the sub- factors related to place to increase the attraction of foreign investors in construction and development of industrial towns in East Azerbaijan province with the relative weight of 0.408 belongs to the factor "liberalization and privatization".

\section{Offers}

The previous sections indicate that the policy made by the government, explained laws, optimal management, facilities in the region and finally place are the most important factors affecting the attraction of foreign investor in order to construct and develop industrial towns and finally leads to the economic growth of the region. Thus, the government, the Ministry of Industries and Mines and the relevant officials should make efforts to adopt appropriate policies, develop constructive international relations, develop custom-tax laws, clarify the adopted laws, create security for foreign investors and allocate facilities in industrial towns in order to increase the economic growth of the region. Furthermore, acquiring knowledge and awareness about the weaknesses and strengths of the capital market, active industries in the region and established towns will help the officials and managers of towns with the economic growth according to the competitiveness of the region. Targeted and efficient plans with modern marketing methods in a clear executive system to attract and encourage foreign investors for construction and development of industrial towns in
East Azerbaijan province are among the basic measures in this area. Planning in the field of providing appropriate facilities according to the modern technology in construction and development of industrial towns, the efforts to attract and transfer the modern knowledge, train experienced people, paying attention to the competitiveness of the region especially East Azerbaijan province according to the politicaleconomic potential of the region and strengthening the powerful and clear foreign relations affect the attraction of foreign investors.

According to the results obtained from the present study, the governments' policy in the field of attracting foreign investor has the maximum effect on the economic growth of the country. Thus, according to the subject area of policy, the analysis of the results obtained from the investments can be performed in future studies. The study of prioritization works in Iran's industries especially the industry of machine-building and tractor manufacturing in East Azerbaijan province and their capital needs can be among the issues to be discussed. The study of the economic-industrial potential of the region in order to highlight the common industries and the attraction of foreign investors' attraction to East Azerbaijan province can help with economic, production and even job creation planning.

\section{References}

1. Yung LL, Feng JL, Yi HL (2015) Factors Affecting Firm's R\&D Investment Decisions. Journal of Business Research 64: 840-844.

2. Morrissey $O$ (2012) Governance, Private Investment and Foreign Direct Investment in Developing Countries. World Development 40: 437-445.

3. Schumacker RE, Lomax RG (2004) A Beginner's Guide to Structural Equation Modeling (2ndedn), Mahwah, New Jersey, Erlbau.

4. Saaty TL (1980) The Analytic Hierarchy Process, Planning, Priority Setting, Resource Allocation. McGraw-Hill, New York, USA.

5. Kline RB (1998) Principles and Practice of Structural Equation Modeling Guilford press, New York, USA. 